\title{
Pengaruh Profitabilitas, Rasio Resiko Bank, dan Kualitas Aktiva Produktif Terhadap Kepercayaan Investor
}

\author{
Hasanah Vidya Putri ${ }^{1}$ \\ Fakultas Ekonomi dan Bisnis \\ Universitas Udayana, Indonesia. \\ Email: hsnhptr@gmail.com
}

\author{
I Ketut Budiartha ${ }^{2}$ \\ Fakultas Ekonomi dan Bisnis \\ Universitas Udayana, Indonesia.
}

\begin{abstract}
ABSTRAK
Penelitian ini bertujuan mengetahui faktor-faktor yang mempengaruhi kepercayaan investor di perbankan syariah. Data yang digunakan dalam penelitian ini diperoleh dari laporan keuangan publikasi perusahaan perbankan syariah 2015-2017 dengan jumlah populasi 36 perusahaan perbankan syariah. Penelitian ini menghipotesiskan profitabilitas, rasio resiko bank, dan kualitas aktiva produktif sebagai variable bebas dan kepercayaan investor sebagai variable terikat. Penelitian ini bertempat di Bursa Efek Indonesia (BEI).Metode sampling menggunakan teknik purposive sampling. Data penelitian diperoleh melalui metode observasi non partisipan dengan pengambilan data sekunder. Analisis data penelitian menggunakan regresi linear bergandadengan aplikasi SPSS. Hasil penelitian ini menunjukkan profitabilitas berpengaruh positif terhadap kepercayaan investor, rasio resiko bank berpengaruh negatif terhadap kepercayaan investor dan kualitas aktiva produktif berpengaruh positif terhadap Kepercayaan Investor. Secara bersamaan semua variabel independen berpengaruh signifikan terhadap variabel dependen.
\end{abstract}

Kata Kunci : Rasio profitabilitas, rasio resiko bank, kualitas aktiva produktif, kepercayaan investor.

\section{The Effect of Profitability, Bank Risk Ratio, and Earning Assets Quality on Investor Trust}

\section{ABSTRACT}

This study aims to determine the factors that influence investor confidence in Islamic banking. The data used in this study were obtained from the financial statements of sharia banking companies published in 2015-2017 with a population of 36 Islamic banking companies. This study hypothesizes profitability, bank risk ratios, and the quality of earning assets as independent variables and investor trust as the dependent variable. This research is located on the Indonesia Stock Exchange (IDX). The sampling method uses a purposive sampling technique. The research data was obtained through non-participant observation methods with secondary data retrieval. Analysis of research data using multiple linear regression with the SPSS application. The results of this study indicate that profitability has a positive effect on investor confidence, the bank's risk ratio has a negative effect on investor confidence and the quality of earning assets has a positive effect on Investor Trust. Simultaneously all independent variables have a significant effect on the dependent variable.

Keywords: Profitability ratio, bank risk ratio, productive asset quality, investor trust.

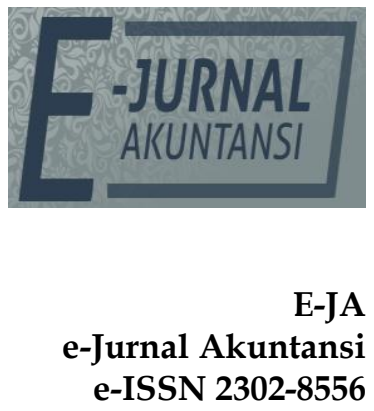

Denpasar,

Vol. 28 No. 3

September 2019

Hal. 2035-2049

Artikel masuk: 28 Juni 2019

Tanggal diterima: 12 Agustus 2019 


\section{PENDAHULUAN}

Pertumbuhan ekonomi erat kaitannya dengan dunia perbankan yang sama-sama berkecimpung dalam bidang keuangan. Pertumbuhan ekonomi itu sendiri merupakan salah satu indikator keberhasilan pembangunan di suatu perekonomian. Kesejahteraan dan kemajuan suatu perekonomian ditentukan oleh besarnya pertumbuhan yang ditunjukkan oleh perubahan output nasional. Oleh sebab itu peranan bank sangatlah penting bagi perekonomian Indonesia serta bank juga mempunyai peranan dalam hal stabilitas keuangan, pengendalian inflasi, sistem pembayaran, serta otoritas moneter (Maruf \& Wihastuti, 2008).

Sektor Perbankan berperan dalam mendorong tingkat pertumbuhan ekonomi dan memperluas kesempatan kerja melalui penyediaan sejumlah dana pembangunan dan memajukan dunia usaha (Handhayani \& Budhiarta, 2015). Bank merupakan lembaga keuangan yang menghimpun dana dan menyalurkannya kepada masyarakat. Bank juga dapat disebut sebagai perusahaan yang memiliki kegiatan operasional dalam meningkatkan kinerja dan mengembangkan usahanya (Yunita, 2014). Setiap perusahaan membutuhkan dana yang cukup dalam menjalankan kegiatan operasinya. Sumber pendanaan perusahaan dapat berasal dari dalam maupun dari luar perusahaan. Dana dari dalam perusahaan merupakan dana dari pemilik perusahaan. Ketika perusahaan sudah berekspansi maka perusahaan perusahaan membutuhkan dana yang besar sehingga manajer membutuhkan tambahan dana, begitu juga dengan bank. Salah satu cara adalah dengan menerbitkan saham melalui pasar modal. Investor yang membeli saham dari bank tersebut akan mengharapkan capital gain dan laba investasi berupa dividen. Tugas dari manajer keuangan ketika investor membeli saham perusahaan adalah mensejahterakan pemilik saham.

Penurunan drastis dari nilai tukar mata uang lokal yang diakibatkan adanya krisis ekonomi, menyebabkan bank-bank konvensional yang memberlakukan sistem bunga dan menganggap uang bukan hanya sekedar berfungsi sebagai alat tukar melainkan telah menjadi barang komoditas, sehingga mereka menaikkan secara besar-besaran bunga pinjaman dan simpanannya. Tingginya tingkat bunga tersebut menyebabkan ekonomi kekurangan likuiditas, yang akibatnya dunia usaha menjadi stagnan, sehingga akhirnya bangkrut dan berakibat meningkatnya pengangguran. Di sisi lain bank harus membayar bunga deposito yang tinggi, sedangkan pendapatan bunganya anjlok karena kredit macet. Akhirnya banyak bank konvensional berbasis bunga, satu per satu gugur terlikuidasi. Dalam keadaan demikian terbukti bank syariah yang non bunga tapi bersistem bagi hasil (profit sharing) lah yang bisa tetap bertahan terhadap tekanan krisis ekonomi. Hal ini disebabkan karena konsep yang mendasari sistem keuangan syariah, menganggap uang hanya sebagai alat tukar. Sehingga uang tersebut tidak akan menghasilkan nilai tambah apapun, kecuali apabila dikonversi menjadi barang atau jasa. Sehingga tiap transaksi keuangan harus dilatarbelakangi transaksi sektor riil (Utami, 2015).

Kehadiran bank tanpa bunga di Indonesia diharapkan dapat meningkatkan pengerahan dana masyarakat dan menyalurkan kembali kepada masyarakat sesuai dengan aturan syariah atau bank tanpa bunga. Kehadiran bank tanpa bunga hakikatnya merupakan suatu simbol lahirnya suatu sistem 
perbankan yang baru mencoba untuk memberikan alternatif lain kepada masyarakat. Bank tanpa bunga merupakan proyek bangsa yang secara bersamasama bank lain diharapkan dapat memberikan peran aktif dalam menggerakan roda pembangunan, sehingga terwujud suatu masyarakat yang adil dan makmur. Lebih dari itu bank tanpa bunga juga diharapkan akan membebaskan sebagian masyarakat khususnya masyarakat muslim dari kegelisahan yang berkepanjangan mengenai bunga bank atau riba. Suatu kegelisahan yang membuat sebagian masyarakat ragu-ragu untuk menggunakan jasa perbakan, dalam hal ini pada gilirannya akan menghambat gerak maju ekonomi dan aktivitas bisnis mereka (Utami, 2015).

Merujuk penelitian terdahulu oleh Abduh (2011) yaitu mengenai kualitas bagi hasil dari bank syariah yang ada di Indonesia. Dalam penelitiannya bank syariah yaitu bank yang menggunakan sistem bagi hasil dalam pelaksanaan operasional perbankan yang mana berbeda dengan bank konvensional yaitu menggunakan sistem bunga atau yang lebih dikenal dengan "riba" di kalangan masyarakat khususnya muslim. Penelitian ini memberikan hasil bahwa system bagi hasil yang digunakan oleh bank syariah yang bertujuan untuk menghindari bunga atau riba berdampak langsung terhadap kepercayaan nasabah.

Di Indonesia, perkembangan ekonomi Islam disertai dengan perkembangannya di bidang Lembaga Keuangan Syariah (LKS) salah satunya adalah bank yang berbasis syariah, sebagai pengaruh dari berkembangnya bankbank syariah di negara-negara islam. Pada awal 1980-an, diskusi mengenai bank syariah sebagai pilar ekonomi islam mulai dilakukan. Akan tetapi, prakarsa lebih khusus untuk mendirikan bank islam di Indonesia baru dilakukan tahun 1990. Lembaga Keuangan Syariah menurut Dewan Syariah Nasional (DSN) adalah lembaga keuangan yang mengeluarkan produk keuangan syariah dan yang mendapat ijin operasional sebagai lembaga keuangan syariah menurut Kumpulan Fatwa DSN -MUI (Buku-II: 2006/2015). Menurut data Otoritas Jasa Keuangan (OJK) pada tahun 2018 bulan Januari pertumbuhan nasabah bank syariah naik 18,05\% pertahun, sedangkan Bank Konvensional Lebih rendah 4-5\% pertumbuhannya dibanding bank syariah yakni hanya mencapai $14 \%$ pertahun. Dilihat dari tingkat pertumbuhan nasabah yang cukup tinggi maka bank syariah saat ini mulai diminati masyarakat di Indonesia.

Perusahaan perbankan yang bertujuan untuk mendapatkan laba yang optimal harus dapat menarik dan menjaga kepercayaan masyarakat dengan cara senantiasa memperhatikan dan meningkatkan profitabilitasnya. Demikian dengan bank, selalu berusaha menyajikan laporan keuangan yang dapat diterima oleh pihak-pihak yang berkepentingan agar dapat memberikan informasi mengenai tingkat kemampuan profitabilitasnya.

Tingkat kemampuan profitabilitas perusahaan akan mudah terlihat dari laporan keuangan, sehingga akan dapat dinilai dan dianalisa oleh para investor yang berkepentingan dengan laporan keuangan tersebut. Dalam melaksanakan usahanya, pengelola bank dituntut untuk senantiasa menjaga keseimbangan antara pemeliharaan likuiditas yang cukup dengan pencapaian profitabilitas yang wajar serta pemenuhan modal yang memadai sesuai dengan jenis penanamannya. Likuiditas dan profitabilitas merupakan hal yang sangat penting 
yang sering menimbulkan dilema bagi pengelola bank dalam melakukan kegiatan operasinya (Sudarmanta, 2016).

Profitabilitas suatu perusahaan akan mempengaruhi kebijakan para investor atas investasi yang dilakukan. Kemampuan perusahaan untuk menghasilkan laba akan dapat menarik para investor untuk menanamkan dananya guna memperluas usahanya, sebaliknya tingkat profitabilitas yang rendah akan menyebabkan para investor menarik dananya. Sedangkan bagi perusahaan itu sendiri profitabilitas dapat digunakan sebagai evaluasi atas efektivitas pengelolaan badan usaha tersebut (Putri, 2017).

Dengan kemampuan tingkat laba yang tinggi, maka perusahaan harus dapat memupuk laba tersebut menjadi tambahan modal sehingga akan meningkatkan dan memelihara tingkat likuiditas pada kondisi yang baik. Selain itu, adanya manipulasi laporan keuangan oleh perusahaan agar dapat terlihat baik kondisi perusahaan tersebut di mata investor, dengan tingkat profitabilitas yang tinggi dan wajar akan menambah tingkat kepercayaan masyarakat untuk menyimpan dananya pada bank tersebut. Tingkat kepercayaan masyarkat akan dapat di tunjukkan melalui jumlah dana yang disimpan oleh masyarakat dan besarnya jumlah investasi atau jumlah modal yang disetor oleh para investor.

Menurut peraturan yang diterbitkan oleh Bank Indonesia (PBI) No.9/1/PBI/2007 tentang sistem penilaian tingkat kesehatan Bank Umum Syariah wajib melakukan penilaian tingkat kesehatan bank secara triwulan, yang meliputi faktor- faktor : permodalan ( capital ), kualitas asset ( asset quality), rentabilitas (Earning), likuiditas ( liquidity), sensitivitas terhadap resiko pasar (sensitivity to market risk), dan manajemen (management).

Risiko adalah potensi kerugian akibat terjadinya suatu peristiwa tertentu (Moussa, 2015). Sedangkan Kandel (2018) menyatakan risiko adalah suatu keadaan kemungkinan timbulnya penghapusan atau bahaya itu dapat diperkirakan sebelumnya dengan menggunakan data yang cukup terpercaya dan relevan. Terdapat beberapa pengertian tentang risiko, yang pada dasarnya tergantung pada jenis kepentingan risiko tersebut. Pada intinya risiko pada umumnya memiliki pengaruh terhadap suatu peristiwa dalam rangka mencapai tujuannya. Sehingga tujuan bank yang telah direncanakan secara matang dapat tercapai (Purnamandari \& Badera, 2015). Dan ada pula pengertian risiko dalam kamus bahasa Inggris yang berbunyi the possibility of loos, harm, injury, disadvantageos destruction, pada kalimat ini semua peristiwa negatif menjadi satu hal yang disebut risiko.

Berbagai usaha yang dilakukan oleh industri perbankan untuk memperoleh profit bukan berarti tidak memiliki risiko pada setiap kegiatan operasionalnya. Dituntut pengelolaan yang profesional disetiap lini untuk memperkecil resiko yang ada agar terhindar dari kerugian.

Pada umumnya, aset berisiko (risky asset) jarang menghasilkan tingkat pengembalian yang diharapkan para investor, aset berisiko mendapatkan lebih baik atau kurang dari yang awalnya diharapkan. Risiko investasi berkaitan dengan profitabilitas yang berproduktif rendah atau pengembalian yang negatif, sangat besar mempunyai peluang pengembalian yang rendah atau negatif, yang berisiko investasi. 
Kualitas aktiva produktif (KAP) sebagai nilai tingkat kemungkinan diterimanya kembali dana yang ditanam dalam aktiva produktif berdasarkan kriteria tertentu. Di Indonesia kualitas aktiva produktif dinilai berdasarkan tingkat ketertagihannya yaitu lancar, dalam penelitian khusus, kredit kurang lancar, kredit diragukan, atau kredit macet. Aktiva produktif merupakan kunci utama pendapatan sebuah bank, sehingga pengelolaan yang baik mutlak dilakukan untuk menjaga kualitas aktiva produktif (Sunarto \& Supriati, 2017).

Sama halnya dengan perbankan konvensional, keberlangsungan usaha bank syariah sangat dipengaruhi oleh kualitas aktiva produktif yang dilakukan. Dalam perbankan syariah, yang dimaksud dengan aktiva produktif adalah penanaman dana bank syariah baik dalam rupiah maupun dalam valuta asing. Penilaian asset suatu bank cenderung kepada penilaian kualitas aktiva produktif (KAP) hal ini dilakukan untuk lebih mengetahui sejauh mana kualitas aktiva yang dimiliki sebagai salah satu faktor pendukung dalam menghasilkan laba pada suatu bank (Nastiti, 2010).

Kesehatan atau kondisi keuangan suatu bank merupakan kepentingan banyak pihak yang terkait seperti pemilik, pengelola (manajemen) bank, pengguna jasa bank serta Bank Indonesia selaku otoritas pengawasan dan pihak lainnya. Penilaian kesehatan bank syariah yang diukur dengan rentabilitas dapat diketahui kondisi dan kemampuan bank dalam menghasilkan laba untuk mendukung kegiatan oprasional dan permodalan serta akan menariknya investor.

Bagi perusahaan papan utama untuk perlu menjaga momentum kepercayaan investor dengan strategi assets growth, growth potential dan likuiditas (Bashir et al., 2013). Perusahaan juga perlu menerapkan strategi likuiditas untuk menambah keyakinan kreditur dan menurunkan risiko bisnis. Perusahaan perlu mengurangi penggunaan utang untuk mengurangi efek risiko terhadap produktivitas aktiva. Strategi yang dibuat perlu lebih fokus pada peningkatan nilai perusahaan dan nilai kreditur. Selain itu, kreditur juga perlu mempertimbangkan risiko keuangan perusahaan dalam memberikan pinjaman (Indriastuti \& Kartika, 2008).

Penelitian mengenai kepercayaan investor telah dilakukan oleh Halimatusadiah (2003) dalam penelitiannya mengenai Pengaruh Profitabilitas dan Rasio Resiko Bank yang Berpengaruh Terhadap kepercayaan Investor menghasilkan bahwa pengujian rasio profitabilitas dan rasio resiko bank berpengaruh signifikan terhadap kepercayaan investor. Pengukuran kepercayaan investor itu sendiri dalam penelitian ini adalah dengan menggunakan jumlah dana pihak ketiga (DPK) yang tersimpan di bank. Pengukuran dengan menggunakan DPK sebelumnya juga sudah dilakukan oleh Rizqyana, et al. (2017) yang mana menjelaskan penggunaan dana pihak ketiga sebagai tolak ukur pengukuran kepercayaan investor. Keuntungan utama bank bersumber dari bagi hasil dana pihak ketiga di setiap transaksi yang dilakukan. Dengan begitu semakin banyak dana pihak ketiga yang diputar untuk memenuhi kebutuhan mudharabah dan murabahah (kredit) masyarakat maka akan semakin banyak laba yang didapatkan dari pengembalian mudarabah dan murabahah tersebut tentunya dengan sistem bagi hasil yang sudah disepakati terlebih dahulu oleh investor. 
Berdasarkan latar belakang penelitian sebelumnya, maka penulis dapat melakukan penelitian dengan judul "Pengaruh Profitabilitas, Rasio Resiko Bank, dan Kualitas Aktiva Produktif Terhadap Kepercayan Investor." Alasan memilih judul ini adalah karena investor adalah sumber utama untuk menambah modal bank itu sendiri, tanpa adanya masyarakat terutama investor maka bank tersebut tidak akan berjalan dan kecilnya dana yang disetorkan oleh masyarakat dipengaruhi oleh berbagai faktor, diantaranya adalah profitabilitas, rasio resiko bank, dan kualitas aktiva produktif. Sehingga perlu di identifikasi rasio tersebut yang mungkin berpengaruh terhadap kepercayaan masyarakat. Profitabilitas yang akan mempengaruhi dalam penelitian ini adalah Return on Assets (ROA), rasio resiko bank menggunakan Non Performing Financing (NPF), sedangkan rasio aktiva produktif menggunakan penghitungan rasio kualitas aktiva produktif (KAP) yang akan digunakan sebagai variabel bebas (independen).

Kemudian kelebihan penelitian yang akan penulis lakukan terhadap penelitian terdahulu adalah merubah periode penelitian serta menambah variabel independen yaitu kualitas aktiva produktif. Metode yang digunakan tidak mengalami perubahan dari penelitian terdahulu sedangkan untuk variabel independennya juga tidak mengalami berubah yaitu tetap menggunakan kepercayaan investor.

Pengungkapan sosial yang dilakukan oleh perusahaan merupakan deal atas tekanan politik dan sosial di masyarakat. Perusahaan adalah bagian dari tujuan sosial.Dengan mengungkapkan informasi sosial dan lingkungan, perusahaan berusaha menyampaikan kepada stakeholder bahwa mereka telah memenuhi tujuan sosial dan lingkungan yang dapat mengurangi tekanan publik. Sehingga perusahaan akan melegitimasi kinerja mereka dengan melakukan pengungkapan sosial dan lingkungan.

Dasar pemikiran teori ini adalah organisasi atau perusahaan akan terus berlanjut keberadaannya jika masyarakat menyadari bahwa organisasi beroperasi untuk sistem nilai yang sepadan dengan sistem nilai masyarakat itu sendiri. Teori legitimasi menganjurkan perusahaan untuk meyakinkan bahwa aktivitas dan kinerjanya dapat diterima oleh masyarakat. Perusahaan menggunakan laporan tahunan mereka untuk menggambarkan kesan tanggung jawab lingkungan, sehingga mereka dapat diterima oleh masyarakat maupun investor. Investor melihat teori ini untuk mengetahui apakah perusahaan beroperasi sudah sesuai dengan nilai masyarakat yang menjadikan perusahaan terlegitimasi dengan baik sehingga investor dapat berinvestasi dalam jangka waktu yang panjang.

Teori sinyal (signaling theory) dikembangkan oleh Ross (1977) yang menyatakan bahwa eksekutif perusahaan yang memiliki informasi dan prospek yang baik mengenai perusahaannya akan cenderung untuk menyampaikan informasi tersebut kepada calon investor agar para investor tertarik untuk menanam saham nya di perusahaan tersebut. Teori sinyal menunjukkan adanya asimetri informasi antara manajemen perusahaan dan pihak-pihak yang berkepentingan dengan informasi tersebut. Teori sinyal mengemukakan tentang bagaimana seharusnya perusahaan memberikan sinyal-sinyal pada pengguna laporan keuangan, terkhusus para investor yang akan melakukan investasi. 
Sinyal ini dapat berupa informasi mengenai apa yang sudah dilakukan oleh manajemen untuk merealisasikan keinginan pemilik (Investor).

Signaling theory juga menjelaskan mengapa perusahaan mempunyai dorongan untuk memberikan infomasi laporan keuangan pada pihak internal. Dorongan perusahaan untuk memberikan informasi tersebut adalah karena terdapat asimetri informasi antara perusahaan dan pihak investor karena perusahaan mengetahui lebih banyak mengenai perusahaan dan prospek yang akan datang dibandingkan dengan pihak pada motivasi signaling manajemen melakukan kebijakan akrual yang mengarah pada presistensi laba. Motivasi signaling mendorong manajemen menyajikan laporan laba yang dapat mencerminkan laba sesungguhnya.

Penelitian yang dilakukan oleh Alamsyah (2017), yang dalam penelitiannya menggunakan rasio profitabilitas seperti gross profit margin, net profit margin, dan rasio resiko bank seperti investmen risk, liqusidity risk, credit risk, asset risk, dan deposit risk, yang akan mempengaruhi kepercayaan investor karena, rasio profitabilitas menunjukan gambaran tentang tingkat efektivitas pengolahan perusahaan dalam menghasilkan laba. Dan dari penelitian baik secara simultan maupun persial semuanya berpengaruh secara signifikan terhadap kepercayaan investor.

$\mathrm{H}_{1}$ : Profitabilitas berpengaruh positif terhadap kepercayaaninvestor.

Dalam penelitian Hosen \& Rahmawati (2016) pada penelitiannya menggunakan pengukuran $\mathrm{BOPO}$, rasio resiko bank yang diukur dengan NPL, rasio likuiditas yang diukur dengan LDR, dan rasio permodalan yang diukur dengan CAR, dan kinerja keuangan diukur dengan rasio profitabilitas ROA yang menunjukan bahwa dalam berinvestasi dipastikan adanya rasiko dalam berinvestasi dan berpengaruh terhadap kepercayaan investor dalam investasinya, karena dalam berinvestasi investor pasti mengharapkan return yang tinggi resiko yang dapat terjadi pada saat berinvestasi ada dua macam yaitu resiko sistematik dan resiko tidak sistematik, investor yang rasional tentunya tidak akan menyukai ketidakpastian dan investor seperti ini tidak akan mau mengambil risiko dari suatu investasi jika investasi tersebut tidak memberikan keuntungan (expected return)yang layak sebagai kompensansi terhadap resiko yang harus ditanggung oleh investor tersebut.

$\mathrm{H}_{2}$ : Rasio Resiko Bank berpengaruh negatif pada kepercayaan investor.

Dalam penelitian Nastiti (2010) dalam penelitiannya dikatakan bahwa modal yang cukup tidak menjamin perolehan laba bank, bila bank tidak memelihara kualitas aset produktifnya. Aset produktif adalah sumber utama pendapatan bank dalam perspektif regulasi, bank diwajibkan untuk memelihara kualitas aset karena aset produktif yang semakin berkualitas tinggi berpotensi menghasilkan pendapatan bagi bank, dan sebaliknya semakin rendah kualitas aset maka semakin rendah kontribusi terhadap pendapatan bank. LDR merupakan rasio penempatan kredit terhadap dana yang di himpun. Semakin tinggi LR, menunjukan semakin tinggi penempatan kredit dibanding sumber dana simpanan. Dengan demikian, semakin tinggi LDR (dimaknai semakin rendah likuiditas) maka semakin tinggi kinerja bank dan disitulah kepercayaan investor dapat tumbuh.

$\mathrm{H}_{3}$ : Kualitas aktiva produktif berpengaruh positif padatkepercayaan investor. 


\section{METODE PENELITIAN}

Penelitian ini dilakukan di Indonesia yaitu bertepat di Bursa Efek Indonessia. Alasan peneliti memilih lokasi penelitian adalah karena data yang dibutuhkan yaitu berupa annual report bank syariah Indionesia secara keseluruhan dari tahun 2015 -2017 terdapat di BEI, selain mempermudah peneliti dalam pengumpulan data juga dapat mempercepat proses pengumpulan.

Populasi dalam penelitian ini adalah Bank Syariah yang variabel $X_{1}$ Profitabilitas, $X_{2}$ Rasio Resiko Bank, $X_{3}$ Kualitas Aktiva Produktif sedangkan variabel $Y$ adalah Kepercayaan Investor.

Metode analisis yang digunakan adalah model regresi linear berganda.Rumus regresi berganda yang digunakan adalah sebagai berikut:

$$
Y=\beta_{0}+\beta_{1} X_{1}+\beta_{2} X_{2}+\beta_{3} X_{3}+\varepsilon
$$

Dimana:

$$
\begin{aligned}
& \mathrm{Y}=\text { Kepercayaan Investor } \\
& \mathrm{X}_{1} \quad=\text { Rasio Profitabilitas } \\
& \mathrm{X}_{2} \quad=\text { Rasio Resiko Bank } \\
& \mathrm{X}_{3} \quad=\text { Kualitas Aktiva Produktif } \\
& \text { Bo } \quad=\text { Konstanta } \\
& \beta_{1}-\beta_{3} \quad=\text { Koefisien Regrsi } \\
& \varepsilon \quad=\text { Error Term }
\end{aligned}
$$

\section{HASIL DAN PENELITIAN}

Hasil statistik deskriptif mengenai pengaruh profitabilitas, rasio resiko bank, dan kualitas aktiva produktif pada tabel 1 sebagai berikut.

Tabel 1. Hasil Analisis Statistik Deskriptif

\begin{tabular}{lrrrrr}
\hline & N & \multicolumn{1}{c}{ Minimal } & Maksimal & Rata - rata & $\begin{array}{c}\text { Std. } \\
\text { Deviation }\end{array}$ \\
\hline Profitabilitas & 36 & $-20,13$ & 11,19 &,- 2533 & 5,342 \\
Resiko Bank & 36 &, 00 & 4,94 & 2,767 & 1,681 \\
Aktiva Produktif & 36 &, 46 & 2,95 & 4,386 & 6,383 \\
Kepercayaan Investor & 36 & 719 & 77903143 & 12077158.18 & $1.957 \mathrm{E} 7$ \\
Valid N (listwise) & 36 & & & & \\
\hline Sulis
\end{tabular}

Sumber: Data Penelitian, 2018

Kepercayaan Investor $(Y)$ dalam penelitian ini dapat didefinisikan sebagai nilai dana pihak ketiga yang masuk ke perusahaan pebankan. Nilai minimal dari kepercayan investor itu sendiri adalah sebesar 719 dan nilai maksimal nya yaitu 77903143. Secara keseluruhan nilai rata-rata sejumlah 12077158,18 dengan standar deviasi 1,957. Dengan nilai rata-rata tersebut maka mengartikan bahwa sebagian besar nilai kepercayaan investor perusahaan perbankan cenderung tinggi.

Profitabilitas $\left(X_{1}\right)$ Sebanyak 36 sampel yang diujikan untuk variabel profitabilitas diketahui bahwa terdapat nilai minimum sebesar -20,13 dan nilai maksimum sebesar 11,19. Diketahui nilai rata-rata menunjukan -0,253 dengan nilai standar deviasi sebesar 5.34291 yang mengartikan bahwa sebagian besar (atau rata-rata) nilai profitabilitas perusahaan perbankan yang diikutkan pada uji cenderung rendah 
Resiko Bank $\left(\mathrm{X}_{2}\right)$, sedangkan untuk variabel Resiko Bank dengan pengujian 36 sampel diketahui bahwa terdapat nilai minimum sebesar 0,00 dan nilai maksimum sebesar 4.94. Diketahui nilai rata-rata menunjukan 2,7672 dengan nilai standar deviasi sebessar 1.68120 yang mengartikan bahwa sebagian besar (atau rata-rata) nilai resiko bank perusahaan perbankan yang diikutkan pada uji cenderung tinggi.

Kualitas Aktiva Produktif $\left(X_{3}\right)$, untuk variabel aktiva produktif dengan pengujian 36 sampel diketahui bahwa terdapat nilai minimum sebesar 0,46 dan nilai maksimum sebesar 29.95. Diketahui nilai rata-rata menunjukan 4,3864 dengan standar deviasi sebesar 6.38361 mengartikan bahwa sebagian besar (atau rata-rata) nilai aktiva perbankan perusahaan perbankan yang diikutkan pada uji cenderung rendah.

Uji normalitas ini bertujuan untuk mengetahui apakah residual dari model regresi yang dibuat berdistribusi normal atau tidak. Dalam penelitian ini uji normalitas dilakukan dengan menguji normalitas residual dengan menggunakan uji Kolmogrov Smirnov. Jika probabilitas signifikansi nilai residual lebih besar dari 0,05 maka data tersebut dikatakan berdistribusi normal. Demikian pula sebaliknya, jika probabilitas signifikansi residual lebih rendah dari 0,05 maka data tersebut dikatakan tidak berdistribusi normal.

Tabel 2. Hasil Uji Normalitas

\begin{tabular}{cc}
\hline & Unstandardized Residual \\
\hline $\mathrm{N}$ & 36 \\
Kolmogrov Smirnov Z & 1,206 \\
Asymp.Sig.(2-tailed) & 0,109 \\
\hline
\end{tabular}

Sumber: Data Penelitian, 2018

Berdasarkan hasil uji normalitas pada Tabel 2 didapat nilai signifikansi sebesar 0,109. Oleh karena nilai signifikansi uji Kolmogorov-Smirnov lebih dari 0,05 maka dapat disimpulkan bahwa model persamaan regresi tersebut berdistribusi normal.

Uji multikolinearitas bertujuan untuk menguji apakah dalam satu model regresi ditemukan adanya korelasi antar variabel bebas. Model regresi yang baik adalah tidak terjadi korelasi diantara variabel bebas. Untuk mendeteksi ada atau tidaknya korelasi antar variabel bebas dapat dilihat dari nilai tolerance dan nilai Variance Inflation Factor (VIF). Jika nilai tolerance lebih dari $10 \%$ atau VIFKurang dari 10, maka dapat dikatakan model telah bebas dari multikolinearitas.

Tabel 3. Hasil Uji Multikoleniaritas

\begin{tabular}{lccc}
\hline \multicolumn{1}{c}{ Variabel } & Tolerance & VIF & Keterangan \\
\hline Profitabilitas $\left(\mathrm{X}_{1}\right)$ & 0,510 & 1,961 & Bebas multikol \\
Resiko bank $\left(\mathrm{X}_{2}\right)$ & 0,575 & 1,740 & Bebas multikol \\
Aktiva produktif $\left(\mathrm{X}_{3}\right)$ & 0,392 & 2,550 & Bebas multikol \\
\hline
\end{tabular}

Sumber: Data Penelitian, 2018

Berdasarkan Tabel 3 dapat dilihat bahwa nilai tolerance dan VIF dari seluruh variable tersebut menunjukkan bahwa nilai tolerance untuk setiap variabel lebih besar dari $10 \%$ dan nilai VIF lebih kecil dari 10 yang berarti model persamaan regresi bebas dari multikolinearitas.

Uji autokorelasi dilakukan untuk melacak adanya korelasi data dari tahun $\mathrm{t}$ dengan tahun $\mathrm{t}-1$ (sebelumnya). Pengujian autokorelasi dilakukan 
melalui Durbin-Watson test, dimana model regresi dikatakan terbebas dari autokorelasi apabila sesuai dengan kriteria $\mathrm{du}<\mathrm{DW}<4$-du. Hasil uji autokorelasi dapat dilihat pada Tabel 4 sebagai berikut.

Tabel 4. Hasil Uji Autokorelasi

\begin{tabular}{cccccc}
\hline No & $\mathrm{dl}$ & $\mathrm{Du}$ & $4-\mathrm{du}$ & $\mathrm{DW}$ & Simpulan \\
\hline 1 & 1,2953 & 1,6539 & 2,3461 & 2,053 & Bebas autokorelasi \\
\hline
\end{tabular}

Sumber: Data Penelitian, 2018

Tabel 4 menunjukkan bahwa besarnya nilai Durbin Watson sebesar 2,053.

Nilai $\mathrm{D}-\mathrm{W}$ menurut tabel dengan $\mathrm{n}=36$ dan $\mathrm{k}=3$ didapat nilai $\mathrm{dl}=1,2953$ dan nilai $\mathrm{du}=1,6539$. Oleh karena nilai $\mathrm{du}<\mathrm{dw}<(4-\mathrm{du})$ yaitu $(1,6539<2,053<2,3461)$, maka dapat disimpulkan tidak terdapat autokorelasi antar residual.

Uji heteroskedastisitas ini bertujuan untuk mengetahui apakah dalam model regresi terjadi ketidaksamaan varians dari residual satu pengamatan ke pengamatan lain yang dilakukan dengan uji Glejser. Model regresi yang baik adalah yang tidak mengandung gejala heteroskedastisitas atau mempunyai varians yang homogen. Jika variabel bebas yang diteliti tidak mempunyai pengaruh signifikan atau nilai signifikansinya lebih dari 0,05 terhadap nilai absolute residual, berarti model regresi tidak mengandung gejala heteroskedastisitas. Hasil pengujian heteroskedastisitas disajikan pada Tabel 5 berikut.

Tabel 5. Hasil Uji Heteroskedastisitas

\begin{tabular}{clcl}
\hline No & \multicolumn{1}{c}{ Variabel Bebas } & Signifikansi & Keterangan \\
\hline 1 & Profitabilitas & 0,902 & Bebas heteroskedastisitas \\
2 & Resiko bank & 0,085 & Bebas heteroskedastisitas \\
3 & Aktiva produktif & 0,255 & Bebas heteroskedastisitas \\
\hline
\end{tabular}

Sumber: Data Penelitian, 2018

Pada Tabel 5 dapat dilihat bahwa nilai signifikansi dari variabel Profitabilitas sebesar 0,902, Resiko bank sebesar 0,085 dan Aktiva produktifsebesar 0,255. Nilai tersebut lebih besar dari 0,05 yang berarti tidak terdapat pengaruh antara variabel bebas terhadap absolute residual. Dengan demikian, model yang dibuat tidak mengandung gejala heteroskedastisitas.

Perhitungan koefisien regresi linier berganda dilakukan dengan analisis regresi melalui software SPSS 18.0 for Windows, diperoleh hasil yang ditunjukan pada Tabel 6.

Tabel 6. Hasil Analisis Regresi Linier Berganda

\begin{tabular}{|c|c|c|c|c|c|c|}
\hline \multirow{2}{*}{\multicolumn{2}{|c|}{ Model }} & \multicolumn{2}{|c|}{$\begin{array}{l}\text { Unstandardized } \\
\text { Coefficients }\end{array}$} & \multirow{2}{*}{$\begin{array}{c}\begin{array}{c}\text { Standardized } \\
\text { Coefficients }\end{array} \\
\text { Beta }\end{array}$} & \multirow[b]{2}{*}{$t$} & \multirow[b]{2}{*}{ Sig. } \\
\hline & & B & Std. Error & & & \\
\hline \multirow[t]{4}{*}{1} & (Constant) & $-0,010$ & 0,092 & & $-0,113$ & 0,911 \\
\hline & Profitabilitas & 0,321 & 0,117 & 0,336 & 2,734 & 0,010 \\
\hline & Resiko bank & $-0,353$ & 0,112 & $-0,367$ & $-3,168$ & 0,003 \\
\hline & Aktiva produktif & 0,310 & 0,142 & 0,307 & 2,187 & 0,036 \\
\hline \multicolumn{2}{|c|}{ Adjusted $R^{2}$} & 0,730 & & & & \\
\hline \multicolumn{2}{|c|}{ F Hitung } & 32,622 & & & & \\
\hline \multicolumn{2}{|c|}{ Sig. F } & 0,000 & & & & \\
\hline
\end{tabular}

Sumber: Data Penelitian, 2018

Berdasarkan hasil analisis regresi linier berganda seperti yang disajikan pada Tabel 6, maka dapat dibuat persamaan regresi sebagai berikut: 


\section{$Y=-0,010+0,321 X_{1}-0,353 X_{2}+0,310 X_{3}$}

Hasil menunjukkan seluruh variabel memiliki nilai signifikansi kurang dari 0,05. Hal ini berarti bahwa terdapat pengaruh yang signifikan dari variabel bebas tehadap variabel terikatnya. Dari persamaan diatas diketahui konstanta sebesar -0,010 artinya apabila semua variabel independen yaitu profitabilitas, rasio resiko bank dan kualitas aktiva produktif, maka kepercayaan investor sebesar $-0,010$.

Koefisien profitabilitas sebesar 0,321 artinya bahwa setiap penambahan $1 \%$ profitabilitas, maka kepercayaan investor bertambah sebesar 0,321 . Koefisien rasio resiko bank sebesar $-0,353$ artinya bahwa setiap penambahan $1 \%$ rasio resiko bank, maka kepercayaan investor menurun sebesar 0,353. Koefisien kualitas aktiva produktif sebesar 0,310 artinya bahwa setiap penambahan $1 \%$ kualitas aktiva produktif, maka kepercayaan investor bertambah sebesar 0,310.

Untuk mengetahui dan mengukur kemampuan model dalam menerangkan variasi variabel independen digunakan koefisien determinasi $\left(R^{2}\right)$. Peneliti menggunakan nilai adjusted $\mathrm{R}^{2}$ pada saat mengevaluasi yang mana model regresi terbaik, karena nilai adjusted $\mathrm{R}^{2}$ dapat naik atau turun apabila satu variabel independen ditambahkan ke dalam model. Hasil uji koefisien determinasi dapat dilihat pada Tabel 6.

Hasil uji memberikan hasil dimana diperoleh besarnya adjusted $\mathrm{R}^{2}$ (koefisien determinasi yang telah disesuaikan) adalah 0,730. Ini berarti variasi Kepercayaan investor dapat dipengaruhi secara signifikan oleh variabel Profitabilitas, Resiko bank dan Aktiva produktifsebesar 73 persen sedangkan sisanya sebesar 27 persen dijelaskan oleh faktor-faktor lain yang tidak dijelaskan dalam model penelitian

Uji ketepatan model regresi bertujuan untuk mengetahui apakah semua variabel bebas yang diidentifikasi (Profitabilitas, Resiko bank dan Aktiva produktif) tepat digunakan memprediksi kepercayaan investor. Uji ini sering juga disebut dengan uji F. Hasil uji F dapat dilihat pada Tabel 6.

Hasil uji $\mathrm{F}$ (Ftest) pada lampiran 7 menunjukkan bahwa nilai $\mathrm{F}$ hitung sebesar 32,662 dengan nilai signifikansi $\mathrm{P}$ value 0,000 yang lebih kecil dari $\mathrm{a}=$ 0,05, ini berarti model yang digunakan pada penelitian ini adalah layak. Hasil ini memberikan makna bahwa ketiga variabel independen yaitu Profitabilitas, Resiko bank dan Aktiva produktif tepat memprediksi atau menjelaskan fenomena kepercayaan investor. Hal ini berarti model dapat digunakan untuk analisa lebih lanjut atau dengan kata lain model dapat digunakan untuk memproyeksikan karena hasil goodness of fitnya baik dengan nilai $\mathrm{F}$ hitung sebesar 32,662 dengan nilai signifikansi P value 0,000 .

Berdasarkan hasil analisis pengaruh Profitabilitas terhadap Kepercayaan investor diperoleh nilai signifikansi sebesar 0,010 dengan nilai koefisien regresi positif sebesar 0,321. Nilai signifikansi 0,010 < 0,050 mengindikasikan bahwa $\mathrm{H}_{0}$ ditolak dan $\mathrm{H}_{1}$ diterima. Hasil ini mempunyai arti bahwa Profitabilitas berpengaruh positif dan signifikan terhadap kepercayaan investor.

Berdasarkan hasil analisis pengaruh Resiko bank terhadap kepercayaan investor diperoleh nilai signifikansi sebesar 0,003 dengan nilai koefisien regresi negatif sebesar $-0,353$. Nilai signifikansi $0,003<0,050$ mengindikasikan bahwa 
$\mathrm{H}_{0}$ ditolak dan $\mathrm{H}_{2}$ diterima. Hasil ini mempunyai arti bahwa Resiko bank berpengaruh negatif dan signifikan terhadap kepercayaan investor.

Berdasarkan hasil analisis pengaruh Aktiva produktif terhadap Kepercayaan investor diperoleh nilai signifikansi sebesar 0,036 dengan nilai koefisien regresi positif sebesar 0,310. Nilai signifikansi 0,036<0,050 mengindikasikan bahwa $\mathrm{H}_{0}$ ditolak dan $\mathrm{H}_{3}$ diterima. Hasil ini mempunyai arti bahwa Aktiva produktifberpengaruh positif dan signifikan terhadap kepercayaan investor.

Hipotesis pertama $\left(\mathrm{H}_{1}\right)$ menyatakan bahwa profitabilitas berpengaruh positif dan signifikan terhadap kepercayaan investor. Hasil analisis dengan melihat nilai signifikansi sebesar 0,010 dengan nilai koefisien regresi positif sebesar 0,321. Nilai signifikansi $0,010<0,050$ mengindikasikan bahwa profitabilitas berpengaruh positif terhadap kepercayaan investor. Hal ini berarti apabila profitabilitas mengalami kenaikan 1 satuan dengan asumsi variabel independen lainnya bernilai konstan, maka kepercayaan investor akan meningkat sebesar 0,321 satuan.

Hipotesis ini mengindikasikan bahwa profitabilitas memberikan pengaruh dan memberikan dampak terhadap kepercayaan investor. Profitabilitas yang tercatat di laporan keuangan perusahaan perbankan tentunya memiliki arti penting terutama bagi para investor maupun nasabah. Hal ini sejalan dengan penelitian yang dilakukan oleh Alamsyah (2017), bahwa Profitabilitas berpengaruh terhadap kepercayaan investor, ini membuktikan adanya persamaan hasil pada beberapa penelitian yang mengindikasikan bahwa rasio profitabilitas menunjukan gambaran tentang tingkat efektivitas pengolahan perusahaan dalam menghasilkan laba. Hal ini dapat terjadi juga dikarenakan kemampuan perusahaan dalam menghasilkan laba sangat baik dengan menggunakan total asset sehingga berpengaruh terhadap kepercayaan investor.

Hipotesis kedua $\left(\mathrm{H}_{2}\right)$ menyatakan bahwa rasio resiko bank berpengruh negative terhadap kepercayaan investor. Hasil analisis dengan menggunakan regresi linear menunjukan rasio resiko bank memiliki tingkat signifikansi sebesar 0,003 dengan nilai koefisien regresi negatif sebesar -0,353. Nilai signifikansi 0,003 $<0,050$ mengindikasikan bahwa $\mathrm{H}_{0}$ ditolak dan $\mathrm{H}_{2}$ diterima. Yang berarti bahwa rasio resiko bank berpengaruh negatif terhadap kepercayaan investor. Dimana nilai koefisiensi regresi sebesar $-0,353$ memiliki arti apabila rasio resiko bank mengalami kenaikan 1 satuan maka kepercayaan investor akan mengalami penurunan sebesar 0,353 satuan.

Hipotesis ini mengindikasikan bahwa rasio resiko bank memberikan pengaruh dan memberikan dampak terhadap kepercayaan investor. Rasio resiko bank yang tercatat di laporan keuangan perusahaan perbankan tentunya memiliki makna penting terutama bagi para investor maupun nasabah. Hal ini sejalan dengan penelitian yang dilakukan oleh Rakhmawati (2013), bahwa rasio resiko bank berpengaruh negatif terhadap kepercayaan investor, hal ini terjadi karena Rasio Resiko Bank berpengaruh pada kesehatan perusahaan tersebut untuk menjadi sorotan atau pandangan para investor untuk dapat menanam modal nya secara aman sehingga rasio resiko bank dapat berpengaruh signifikan terhadap kepercayaan investor.

Hipotesis ketiga $\left(\mathrm{H}_{3}\right)$ menyatakan bahwa kualitas aktiva produktif bank 
berpengaruh positif terhadap kepercayaan investor. Hasil analisis dengan menggunakan regresi menunjukan kualitas aktiva produktif memiliki tingkat signifikansi sebesar 0,036 dengan nilai koefisien regresi negatif sebesar 0,310. Nilai signifikansi 0,003 $<0,050$ mengindikasikan bahwa $\mathrm{H}_{0}$ ditolak dan $\mathrm{H}_{3}$ diterima. Yang berarti bahwa kualitas aktiva produktif berpengaruh positif terhadap kepercayaan investor. Dimana nilai koefisiensi regresi sebesar 0,310 memiliki arti apabila rasio resiko bank mengalami kenaikan 1 satuan maka kepercayaan investor akan mengalami peningkatan sebesar 0,310 satuan.

Hipotesis ini mengindikasikan bahwa kualitas aktiva produktif memberikan pengaruh dan memberikan dampak terhadap kepercayaan investor. Kualitas aktiva produktif yang tercatat di laporan keuangan perusahaan perbankan tentunya memiliki arti penting terutama bagi para investor maupun nasabah. Hal ini sejalan dengan penelitian yang dilakukan oleh Nastiti (2010), bahwa Profitabilitas berpengaruh terhadap kepercayaan investor, ini membuktikan adanya persamaan hasil pada penelitian yang mengindikasikan bahwa aset produktif adalah sumber utama pendapatan bank dalam prespektif regulasi dimana bank diwajibkan untuk memelihara kualitas asetnya, aset produktif yang semakin berkualitas tinggi berpotensi mengasilkan pendapatan bagi bank dimana kepercayaan investor dapat tumbuh untuk menanamkan modalnya.

Penelitian ini diharapkan dapat memberikan wawasan dan pengetahuan yang lebih mendalam secara teoritis kepada mahasiswa mengenai hubungan pengaruh profitabilitas, rasio resiko bank, dan kualitas aktiva produktif terhadap kepercayaan investor yang dapat mendukung teori legitimasi dan teori sinyal serta studi mengenai masalah yang tersaji dalam tulisan ini dapat menambah referensi pustakaan dalam bidang akuntansi khususnya mahasiswa Universitas Udayana.

Hasil penelitian ini diharapkan dapat dijadikan sebagai bahan informasi dan masukan serta sumbangan pemikiran mengenai profitabilitas, resiko bank, serta aktiva produktif suatu perusahaan perbankan syariah yang terdaftar di Bursa Efek Indonesia dengan melihat dari bahan referensi dasar-dasar pemikiran bagi para pengguna informasi yang berkaitan dengan kegiatan operasional perbankan. bagi para investor serta dapat menjadi referensi dalam pengambilan keputusan bagi manajemen dan investor perusahaan.

\section{SIMPULAN}

Dari hasil penelitian yang sudah dijelaskan dibab sebelumnya menunjukan bahwa profitabilitas berpengaruh positif dan signifikan terhadap kepercayaan investor dengan ini berarti hipotesis pertama diterima. Artinya semakin tinggi tingkat profitabilitas perbankan maka tingkat kepercayaan investor akan meningkat. Dengan meningkatnya profitabilitas perbankan maka akan menambah kepercayaan nasbah dan investor untuk menyalurkan dananya dalam berupa tabungan, giro, ataupun deposito di bank tersebut.

Dari hasil penelitian yang sudah dijelaskan dibab sebelumnya menunjukan bahwa rasio resiko bank berpengaruh negatif dan signifikan terhadap kepercayaan investor dengan ini berarti hipotesis kedua diterima. 
Artinya kredit macet yang tinggi akan berdampak buruk terhadap kinerjanya perbankan dan akan mempengaruhi tingkat kepercayaan investor.

Dari hasil penelitian yang sudah dijelaskan dibab sebelumnya menunjukan bahwa kualitas aktiva produktif berpengaruh positif dan signifikan terhadap kepercayaan investor dengan ini berarti hipotesis ketiga diterima. Artinya bahwa semakin tinggi aktiva produktif maka semakin tinggi tingkat kepercayaan investor. Dengan nilai relatif besarnya jumlah asset, maka akan menumbuhkan kepercayaan masyarakatuntuk menabung ataupun mendepositkan dananya pada bank tersebut dan apabila asset tersebut dikelola secara tepat guna, maka akan mampu mendorong profitabilitasnya.

Bank Syariah yang menerapkan sistem bagi hasil dalam mekanisme penyaluran dananya kepada masyarakat harus lebih selektif dalam memilih nasabah pembiayaan mudharabah untuk menghindari angsuran tidak lancar dan tetap mengacu pada Peraturan Bank Indonesia Nomor 9/1/Pbi. 2007, disamping itu juga pelayanan jasanya kepada masyarakat diupayakan semakin diperluas dan tidak dibatasi pada kelompok masyarakat tertentu saja. Bagi peneliti selanjutnya, disarankan untuk meningkatkan kualitas penelitiannya dengan menambah variabel- variabel tertentu yang relevan dan periode penelitiannya lebih terkini.

\section{REFERENSI}

Abduh, Muhamad. (2011). Islamic Banking Service Quality and Withdrawal Risk: The Indonesian Experience. International Journal of Excellence in Islamic Banking and Finance Vol.1

Alamsyah, Sustari. (2017). Pengaruh Profitabilitas Terhadap Nilai Perusahaan, Relevansi Nilai Informasi Akuntansi, Keputusan Investasi, Kebijakan Dividen Sebagai Variabel Intervening (Studi Empiris Pada Perusahaan Indeks Kompas 100 Periode 2010-2013). Competitive, Vol. 1 No. 1. : 137-161

Bashir, D. T., Javed, A., Butt, A. A., \& Azam, N. (2013). An Assessment Study on the Factors Influencing the Individual Investor Decision Making Behavior. IOSR Journal of Business and Management, 9(5), 37-44.

Halimatusadiah, Elly. (2003). Pengaruh Profitabilitas dan Rasio Resiko Bank terhadap Kepercayaan Investor pada Bank Muamalah Indonesia. Jurnal Akuntansi. Vol 2

Handhayani, Ni Wayan Surya Dan I Ketut Budiartha. (2015). Pengaruh Size, Profitabilitas, Loan To Deposit Ratio, Dan Kecukupan Modal Terhadap Opini Audit Going Concern. E-Jurnal Akuntansi Universitas Udayana 11.3 (2015): 771-787.

Hosen, Muhammad Nadratuzzaman Dan Rafika Rahmawati. (2016). Efficiency And Profitability On Indonesian Islamic Banking Industry. Jurnal Ilmu Ekonomi Syariah. Journal Of Islamic Economics, volume 8 (1) , Page 33 - 48.

Indriastuti, Maya dan Indri Kartika.(2008). Kepercayaan Investor Terhadap Kinerja Perbankan Go Public Di Bursa Efek JakartaJurnal Keuangan diPerbankan, Vol. 12, No.1 Hal. 127 - 135.

Kandel, Laxman Raj. (2018). Risk and Return Analysis of Commercial Banks of Nepal. Pravaha Journal pages: 109-119. 
Moussa, Mohamed Aymen Ben. 2015. The Relationship between Capital and an Risk: Evidence from Tunisia. International Journal of Economics and Finance; Vol. Page : 223-232.

Nastiti, Ganjar Putri. 2010. Pengaruh Kualitas Aktiva Produktif Dan Profitabilitas Terhadap Kinerja Keuangan Bank Yang Go Public Di Indonesia Tahun 2005-2009. Jurnal Ekonomi Pembangunan, Vol 8 No.

Peraturan Bank Indonesianomor 9/1/Pbi. 2007. Tentang Sistem Penilaian Tingkat Kesehatan Bank Umum Berdasarkan Prinsip Syariah. Gubernur Bank Indonesia.

Peraturan Bank Indonesia Nomor 7/2/PBI/(2005) tentang. Penilaian Kualitas Aktiva Bank Umum, definisi dari aktiva produktif. Gubernur Bank Indonesia.

Purnamandari, Ni Putu Ayu Lisna Dan I Dewa Nyoman Badera (2015). Kemampuan Prediksi Rasio Keuangan Dan Ukuran Bank Pada Risiko Gagal Bank. E-Jurnal Akuntasi Universitas Udayana 12.2 : 172-187

Putri, Merlia Triyana. (2017). Pengaruh Profitabilitas Dan Keputusan Investasi Terhadap Nilai Perusahaan Pulp \& Paper Yang Terdaftar di Bursa Efek Indonesia. Jom Fisip Volume Hal: 1-12.

Rakhmawati, D. (2013). Indonesia, Analisis Laporan Keuangan untuk Menilai Kinerja Keuangan pada Perusahaan Perbankan yang Terdaftar di Bursa Efek. STIE Perbanas Surabaya.

Rizqyana, N. R., Norita, \& Zultilisna, D. (2017). Analisis Pengaruh Dana Pihak Ketiga, Risiko Kredit, Risiko Likuiditas Dan Risiko Kecukupan Modal Terhadap Profitabilitas Bank Umum Yang Terdaftar Di Bursa Efek Indonesia Periode 2011-2015. Jurnal Sains Manajemen dan Akuntansi STIE STAN - IM, 9(1).

Ross, Stephen.A.(1977). The Determination Of Financial Structure: The Incentive Signaling Approach.The bell journal of economics, Vol.8, No.1, pp23-40.

Sudarmanta, I Ketut. 2016. Determinasi Profitabilitas Sektor Perbankan Di Bursa Efek Indonesia. Jurnal Ekonomi \& Bisnis Vol. 3 Hal 13-21.

Sudarsono, Heri. (2017). Analisis Pengaruh Kinerja Keuangan terhadap Profitabilitas Bank Syariah di Indonesia. Economica: Jurnal Ekonomi Islam - Volume 8, Nomor 2: 175 - 203

Sunarto, Nazrantika dan Supriati (2017). Pengaruh Kualitas Aktiva Produktif Terhadap Return On Assets (Studi Pada Bank Umum Yang Listing Di Bursa Efek Indonesia Tahun 2006-2010 ).Jurnal Inovasi dan Bisnis, Vol. 5, hal3-11.

Utami, Wikan Budi. (2015). Perkembangan Perbankan Bagi Hasil Di Indonesia. Jurnal Ilmiah Ekonomi Islam Vol. 01, No. 01 Hal: 29-36.

Yunita, Rima. (2014). Faktor-Faktor Yang Mempengaruhi Tingkat Profitabilitas Perbankan Syariah Di Indonesia (Studi Kasus Pada Bank Umum Syariah Di Indonesia Tahun 2009 -2012). Jurnal Akuntansi Indonesia, Vol. 3 No. 2, Hal. $143-160$. 